\title{
Non-Transgenic Functional Rescue of Neuropeptides
}

Elizabeth M. DiLoreto ${ }^{1} \uparrow$, Douglas K. Reilly ${ }^{1,2} \uparrow$, Jagan Srinivasan $^{1,3^{*}}$

${ }^{1}$ Department of Biology and Biotechnology, Worcester Polytechnic Institute, Worcester, MA, USA

${ }^{2}$ Current Position: Department of Biology, Tufts University, Medford, MA, USA

${ }^{3}$ Neuroscience Program, Worcester Polytechnic Institute, Worcester, MA, USA

$\uparrow$ These authors contributed equally to this work.

* Corresponding author. email: jsrinivasan@wpi.edu 


\section{Abstract}

Animals constantly respond to changes in their environment and internal states via neuromodulation. Neuropeptide genes modulate neural circuits by encoding either multiple copies of the same neuropeptide or different neuropeptides. This architectural complexity makes it difficult to determine the function of discrete and active neuropeptides. Here, we present a novel genetic tool that facilitates functional analysis of individual peptides. We engineered Escherichia coli bacteria to express active peptides and fed loss-of-function Caenorhabditis elegans to rescue gene activity. Using this approach, we rescued the activity of different neuropeptide genes with varying lengths and functions: trh-1, ins-6, and $p d f-1$. While some peptides are functionally redundant, others exhibited unique and previously uncharacterized functions. The mechanism of peptide uptake is reminiscent of RNA interference, suggesting convergent mechanisms of gene regulation in organisms. Our rescue-by-feeding paradigm provides a high-throughput screening strategy to elucidate the functional landscape of neuropeptide genes regulating different behavioral and physiological processes. 


\section{$\underline{\text { Introduction }}$}

\section{Neuropeptide Signaling is Complex}

When presented with a host of environmental cues, organisms' sense, interpret, and enact appropriate responses to stimuli ${ }^{1,2}$. The interpretation and integration of stimuli is a dynamic process that requires neural circuits to be flexible to elicit the proper behavior. For example, a single stimulus can drive multiple reactions depending on internal or environmental states of the organism ${ }^{3}$. In the roundworm Caenorhabditis elegans, when presented with the same small molecular cue (ascr\#3), the sexes respond differently: males are attracted while hermaphrodites avoid the cue ${ }^{4-6}$. Indole elicits different reactions depending on the amount present in the environment. At low concentrations, indole is attractive with a pleasant, floral aroma, though at high concentrations, it is repulsive, smelling pungent, reminiscent of feces or $\operatorname{rot}^{7,8}$.

To modulate competing behaviors in response to the same cue, for example, different neurons can be involved at the circuit level or changes can occur at the synaptic level. A more dynamic approach for modulating neural responses is peptidergic signaling. Neuropeptides are short amino acid chains that serve to regulate neural circuits, while also functioning as neurotransmitters and neurohormones ${ }^{9,10}$. Neuropeptides signal on longer time scales than, though often in concert with neurotransmitters to regulate synaptic activity, typically through G-protein coupled receptor signaling cascades ${ }^{10,11}$. Multiple modulators allow neurons to serve unique functions within discrete neural circuits ${ }^{12}$.

Neuropeptides serve a broad array of functions across the animal kingdom. Oxytocin-like and vasopressin-like peptides are neurohormones that regulate social attachment, lactation, and blood pressure by contracting muscles in mammals, dating back $600-700$ million years ${ }^{13-18}$. However, in the Echinoderm sea star, Asterias rubens, vasopressin-like and oxytocin-like neuropeptide 
ortholog asterotocin serves instead to in relax muscles in the cardiac stomach during fictive feeding 18. The C. elegans vasopressin ortholog, nematocin, interacts with serotonin and dopamine signaling to modulate gustatory associative memory and male mating behaviors ${ }^{13,19}$.

C. elegans are a microscopic nematode that displays robust behaviors driven by just over 300 neurons ${ }^{20,21}$. The $C$. elegans genome encodes three classes of neuropeptides: FMRFamide-like peptides (FLP), insulin-like peptides (INS), and non-FLP/insulin neuropeptide-like peptides (NLP) ${ }^{22-24}$, encoding over 300 individual neuropeptides through 131 genes that modulate the functional connectome ${ }^{9,25,26}$. The complexity of the neuropeptide genome, combined with extrasynaptic neuropeptides signaling makes elucidating the role of individual peptides difficult, as canonical studies often rely on null mutations and transgenic rescues ${ }^{27-30}$. As such, these studies are often incomplete, as full gene rescue restores complete preproproteins and makes discrimination of discrete peptide function impossible ${ }^{9,31}$. Here we present a strategy that rescues neuropeptides synthesized endogenously within the worm genome via engineered bacteria expressing individual peptides.

\section{Development of Rescue-by-Feeding Paradigm}

Current methods of genetic rescue in Caenorhabditis elegans are not ideal for understanding the function of individual peptides; whether by cost inhibition or equipment limitations ${ }^{32,33}$ or due to whole gene rescue not being ideal for studying discrete peptides ${ }^{34-37}$. Feeding of peptides via E. coli has proven successful in manipulating C. elegans biological function. Feeding the scorpion venom protein, mBmKTX, modulates lifespan and egg laying behaviors ${ }^{38}$.

Neuropeptide rescue-by feeding, outlined here, expands on RNA interference (RNAi) feeding paradigms, which have been successfully used to test gene function ${ }^{39,40}$, wherein a plasmid encoding the RNA of interest is driven by isopropyl- $\beta$-D-thiogalactoside (IPTG) -induction. 
Wherein RNAi employs paired T7 promoters facing one another to produce double-stranded RNA, our protocol uses one T7 promoter to generate mRNA encoding the peptide of interest. The use of Gateway Cloning to develop expression vectors allows for the development of high-throughput experiments targeting individual peptides, or combinations thereof ${ }^{41},{ }^{42}$ (Figure 1a). Additionally, this technique is readily accessible compared to traditional transgenic rescue approaches.

The paradigm rescues individual, processed neuropeptides, leveraging the genetic amenability of the C. elegans food source, Escherichia coli, to circumvent the need for transgenic development and enable high-throughput rescue and elucidation of individual neuropeptide function. We demonstrate the application of this paradigm by rescuing behaviors driven by neuropeptides synthesized from trh-1, ins-6, and $p d f-1$ (Figure 1b).

\section{$\underline{\text { Results and Discussion }}$}

Functional Redundancy of Thyrotropin-Releasing Hormone (TRH)-like Peptides in $C$. elegans

Recent work has revealed that $C$. elegans express homologs of mammalian thyrotropinreleasing hormone (TRH) ${ }^{43}$. Expression of the nematode gene, trh-1, in the pharyngeal motor neurons M4 and M5 results in the production of a TRH-like neuropeptide precursor that is processed into two matured peptides: TRH-1A (GRELF-NH 2$)$, and TRH-1B $(\text { ANELF-NH })^{31,43}$. Like FLP and other NLP peptides, these peptides are also flanked by di/tribasic residues, allowing them to be processed by EGL-3 ${ }^{44,45}$.

In mammals, TRH is essential for proper metabolism and growth ${ }^{46}$, and can even induce metamorphosis in certain amphibians ${ }^{47}$. The initial characterization of trh-1 and the cognate receptor gene, $t r h r-1$, revealed a similar role within the $C$. elegans nervous system ${ }^{43}$. Animals 
expressing a trh-1 pro-peptide that is truncated prior to peptide translation due to an 8 -bp indelframeshift are significantly shorter and thinner than their wild-type counterparts, resulting in a relative body volume defect (Figure 1b, Size Comparisons), 48-hours after larval stage 1 (L1) arrest (Mann-Whitney test, $p=0.0012$ ) (Figure 2a) ${ }^{43}$. In-vitro studies involving biochemical activation of the TRHR-1 receptor by either peptide (TRH-1A or TRH-1B) suggests functional redundancy of these peptides in rescuing body volume defect in trh-1 animals ${ }^{43}$.

We cloned both TRH-1 peptides; TRH-1A and TRH-1B in our expression vector as described in Figure 1. trh-1 loss-of-function (lof) mutant animals fed scramble peptide (SCRAMBLE, NSKLHRGGGRSRTSGSTGSMASHARGSPGLQ-NH2) expressed in E. coli DH5a cells experience a significant increase in their body volume compared to wild-type animals (KruskalWallis followed by Dunn's multiple comparison test, $p=0.0015$ ) (Figure 2b). However, feeding trh-1 lof animals with E. coli bacteria expressing either TRH-1A, or TRH-1B (trh-1 lof versus TRH-1A or TRH-1B fed, $p<0.0001$ ) or a combination of both TRH-1A and TRH-1B peptides resulted in a complete restoration of wild-type body volume $(t r h-1$ lof versus TRH-1A+B fed, $p=$ 0.0019; wild-type versus TRH-1A+B fed, $p>0$ 09999) (Figure 2b, Supp. Figure 1a-b, c-h for length, width and area). This suggests that feeding bacteria expressing TRH-1A or TRH-1B, or a combination of the two peptides, to trh-1 mutant animals results in rescue of body volume, suggesting that they are functionally redundant. While transgenic C. elegans expressing the fulllength trh-1 gene under its endogenous promoter restores wild-type body volume ${ }^{43}$, the role of individual peptides (TRH-1A and TRH-1B) in regulating this phenotype was not addressed. Our rescue-by-feeding strategy offers an easy, high-throughput in vivo biological confirmation of function. 
An interesting observation we noticed is that the quality of food determines the body morphology phenotype in trh-1 mutant worms (Figure 2a, b). trh-1 mutant worms when fed on the standard food source, E.coli OP50, displayed reduced body volume as previously published (Figure 2a) ${ }^{43}$. However, trh-1 lof worms reared on E. coli DH5 $\alpha$ cells exhibited increased body volume compared to wildtype animals raised under similar conditions (Figure 2b). In addition, we observed that other body morphology characteristics such as relative body length (Supp. Figure 1c, d), width (Supp. Figure 1e, f), and area (Supp. Figure 1g, h) are different in worms fed with E. coli DH5 $\alpha$ compared to E. coli OP50 fed animals. E. coli OP50 strain, an uracil auxotroph is the most commonly used laboratory bacterial food source as it grows in thin lawns which allow easier visualization of worms ${ }^{48}$. However, studies have shown that $C$. elegans prefer other more nutritious bacteria such as HB101 or Comamonas sp. for its nutrition ${ }^{49}$. We propose that the reduced body volume defect in trh-1 lof worms reared on E. coli OP50 could be a result of an inefficiency of nutrient absorption due to a difference in the nutrient composition of the two E. coli strains DH5 $\alpha$ and OP50. Our studies corroborate previous literature, wherein trh-1 mutant worms reared on E. coli HB101 exhibit no defect in relative body volume in compared to E. coli OP50 fed animals ${ }^{43}$.

\section{Feeding of INS-6 Peptides Rescues Chemotaxis Defects Exhibited by ins-6 Mutants}

Insulin and insulin-like peptides serve signaling functions in Drosophila and C. elegans homologous to the human insulin-like growth factor (IGF), which regulates FOXO activity ${ }^{50}$. In C. elegans, ins-6 encodes only one processed INS-6 peptide (VPAPGETRACGRKLISLVMAVCGDLCNPQEGKDIATECCGNQCSDDYIRSACCP-NH ${ }_{2}$ )

51,52 , though the gene was originally postulated to encode two putative proteins ${ }^{9,23}$. ins- 6 functions 
in dauer formation ${ }^{51,53}$ and sensory modulation of large fluctuations in salt concentration, with loss of ins- 6 causing dysfunction of $\mathrm{NaCl}$ attraction (Figure 1b, Chemotaxis) ${ }^{54}$.

While wild-type worms were attracted to high concentrations of salt $(750 \mathrm{mM})$, there was a significant decrease in attraction in ins- 6 mutant animals, as measured by a Chemotaxis Index (CI) (Paired $t$-test with samples of equal variance, $p=0.0248$ ) (Figure 3a) ${ }^{54}$. Salt attraction was partially rescued with genetic reintroduction of ins- 6 under its endogenous promotor (Figure 3a). Similarly, the CI of ins-6 lof animals fed scramble peptide was significantly different from the wild-type animals fed scramble (Figure 3b). Feeding of E. coli expressing INS-6 peptide to ins-6 lof animals resulted in a complete restoration of attraction to high salt concentration (ANOVA, followed by Bonferroni's Correction, ins- 6 lof fed scramble versus INS-6 fed, $p=0.0101$ ) (Figure 3b).

Overexpression of INS-6 did not increase chemotaxis towards high salt, as wild-type animals fed INS-6, along with a full ins-6 genetic rescue, exhibited slight defects in CI towards high salt (ANOVA, followed by Bonferroni's Correction, wild-type versus fed, $p=0.08071$; wild-type versus transgenic overexpression, $p=0.2403$ ) (Supp. Figure 2b). Partial genetic rescue of ins-6 limited to the ASI sensory neuron (ins-6;ASI::ins-6) was sufficient to rescue neurophysiological function of $\mathrm{AWC}^{\mathrm{ON}} \mathrm{NaCl}$ sensation ${ }^{54}$, though it was not sufficient for rescuing behavioral attraction to salt (ANOVA, followed by Bonferroni's Correction, $p=0.2136$ ) (Supp. Figure 2b). While our rescue-by-feeding paradigm was able to rescue the behavioral phenotypes of aberrant ins-6 signaling, the ability to combine this method with calcium imaging techniques is still in development. 


\section{Differential Functional Activity of Peptides Encoded by Pigment Dispersing Factor (pdf)-1}

Wild-type males display a characteristic exploratory behavior when left on a lawn of food, as well-fed males leave food in search of mates ${ }^{55,56}$. The pigment dispersing factor $p d f-1$ neuropeptide plays a significant role in male mate-searching behavior, balancing the neural circuits controlling two predominant male interests: finding food and finding mates ${ }^{55,57}$. Like $t r h-1$, the $p d f-1$ precursor encodes two neuropeptides: PDF-1A (SNAELINGLIGMDLGKLSAVG-NH ${ }_{2}$ ) and PDF-1B (SNAELINGLLSMNLNKLSGAG-NH $)^{58,59}$.

We quantified the behavioral activity of $p d f-1$ lof males using a food-leaving behavior as previously described ${ }^{55,60}$. Individuals were placed on a small food spot, and track patterns were scored at three different time points (2, 6, $24 \mathrm{hrs)}$ (Figure 4a). "Never left food" indicate the absence of tracks outside the food spot. "Minor excursion"' indicates that tracks were observed not beyond $1 \mathrm{~cm}$ from the food. "Major excursion" indicates the presence of tracks past the $1 \mathrm{~cm}$ boundary (Figure 1b, Excursion Assay). We additionally quantified this food-leaving behavior as a measure of mate-searching behavior. In this behavior well-fed males left food in search of mates and the data is represented as a Probability of Leaving $\left(\mathrm{P}_{\mathrm{L}}\right)\left(\right.$ Supp. Figure 3a, b) ${ }^{55,56}$.

$p d f-1$ lof males did not leave food as readily as wild-type worms suggesting that these worms do not display exploratory behavior, as previously described (Paired $t$-test with samples of equal variance, $p<0.0001$ ) (Supp. Figure 3b, c) ${ }^{55}$. When fed either PDF-1 peptide (or a 1:1 combination of both), $p d f-1$ lof males had a higher $\mathrm{P}_{\mathrm{L}}$ compared to scramble fed $p d f-1$ lof males (ANOVA, followed by Bonferroni's Correction, $p<0.0001$ ) (Figure 4b). However, PDF-1B and a 1:1 ratio of both peptides resulted in a significantly different $\mathrm{P}_{\mathrm{L}}$ from $p d f-1$ males fed PDF-1A alone (ANOVA, followed by Bonferroni’s Correction, $p<0.0001$ ). Rescue-by-feeding resulted in 
a partial rescue: while the $\mathrm{P}_{\mathrm{L}}$ of peptide-fed males were significantly higher than $p d f-1$ lof males fed scramble, they were still significantly lower than wild-type males fed scramble peptide (ANOVA, followed by Bonferroni's Correction, $p<0.0001$ ) (Figure 4b). Future studies employing this paradigm can now focus on teasing apart the difference in PDF-1A and PDF-1B function in mate-finding behavior, as we have successfully employed in dissecting FLP-3 peptide functions ${ }^{61}$.

We present here a method of neuropeptide rescue that exploits bacterial expression to deliver individual peptides to rescue behavioral and growth-related phenotypes. We show that while some peptides are redundant in function (Figure 2), others rescue phenotypes driven by large peptides (Figure 3), while novel functions are displayed by other peptides over long timescales (Figure 4). Our novel technology to rescue peptide function is advantageous over transgenic studies, as it allows for functional characterization of individual peptides. This genetic tool is built off the principles of RNAi feeding techniques to supply worms with the peptide of interest through their food source as previously shown for the scorpion venom peptide mBmKTX to alter lifespan and egg-laying behavior in C. elegans ${ }^{38}$. More recently, we have improved upon this paradigm to characterize the FMRFamide-like peptide gene, $f l p-3{ }^{61}$. This gene encodes ten different peptides and we leveraged the rescue-by-feeding technology to elucidate that only two of the ten peptides encoded by the precursor are active in controlling the behavioral response of males to a mating pheromone ${ }^{61}$. These studies support the assertion that feeding peptides to C. elegans via their $E$. coli food source is sufficient to rescue mutant phenotypes.

Based on our results, we propose that the neuropeptide rescue-by-feeding strategy delivers mRNA ready for translation by the $C$. elegans cellular machinery, rather than supply $C$. elegans with fully translated and processed peptides. The plasma membrane of a cell is an intricate complex 
of multiple lipid and protein molecules. Small molecules with moderate polarity diffuse through the cell membrane passively, but most metabolites and short peptides require specialized membrane transporters for translocation ${ }^{62}$. Given the large number of neuropeptides encoded in the genome of C. elegans ${ }^{9}$, having specialized transporters for peptide transport is not feasible ${ }^{63}$. The strongest piece of evidence for this statement lies in that the processed INS- 6 peptide is 54 amino acids in length: the $C$. elegans intestine expresses peptide transporters that only uptake smaller, inactive di- and tri-amino acid peptide chains ${ }^{63}$. Thus, rescue of chemotaxis behavior by INS-6 peptide feeding (Figure 3b) suggests that the mechanism of rescue may be similar to double-stranded RNA (dsRNA) uptake, rather than peptidergic transport across the intestinal membrane ${ }^{64,65}$. Furthermore, previous studies have shown that dsRNA exhibit transgenerational inheritance ${ }^{66}$, despite degradation rates,. Our rescue of the exploratory behavior of $p d f-1$ lof males even in the 24-hour timescale (Figure 4) suggest that our feeding paradigm exploits similar mechanisms, allowing peptide-encoding mRNAs to remain present throughout the assay. We propose that if peptides were taken up, their degradation rates would likely impede rescue efficiency at later timepoints unlike what we observe in our experiments suggesting that the mechanism is similar to double-stranded RNA (dsRNA) feeding, with mRNA uptake driving rescue rather than peptide uptake.

Feeding E. coli DH5a expressing peptides results in altered phenotypes compared to E. coli OP50 (Figure 2, 3) and (Reilly et al., in review) ${ }^{61}$. Future studies will focus towards optimizing experimental protocols for feeding. Two areas of optimization we envision involve designing an expression vector strategy that can multiplex multiple neuropeptide genes and finding the "best" food source for the rescue experiments. Given the differences in nutrient composition of the 
different $E$. coli strains and worms preferring more nutritious bacteria ${ }^{49}$, expressing peptides in HB101 or HB115 strains offer viable alternatives.

Understanding neuropeptide function is essential both from a perspective of regulation of neuronal (synaptic and non-synaptic) channels of communication, and form a global view of general neuronal functional assignments throughout the brain. Revealing how a particular neuropeptide acts both at the cellular and subcellular peptide receptor level is critical link in understanding the role of neuromodulation of circuits. An enhanced experimental pipeline to investigate peptide function will enable progress toward answering how neural circuit activity within the network in its different states and identification are modulated by neuropeptides, resulting in flexible decision-making during behaviors. 


\section{Methods}

\section{C. elegans strains}

The C. elegans strains N2 and CB4088 (him-5(e1490)) were obtained from the Caenorhabditis Genetics Center. The LSC1118 (trh-1(lst1118)) strain was generously provided by Isabel Beets at KU Leuven for the body morphology tests. The strains used in the Chemotaxis Assay were gifted by Prof. Shreekanth Chalasani, Salk Insitutute (IV302 (ins-6(tm2416); kyEx2595) at the Salk Institute, and Yun Zhang (ZC239 (ins-6(tm2416)II; yxEx175[Pins-6::ins-6; Punc-122::gfp]) at Harvard University. The UR954 (pdf-1(tm1886); him-5(e1490)) strain was provided by Douglas Portman at the University of Rochester.

\section{$\underline{\text { Peptide plasmid design and generation }}$}

DNA sequences encoding individual peptides were identified via www.wormbase.org. Sequences were flanked with the endogenous cleavage sites for the EGL-3 processing enzyme, which cleaves dibasic resides. Sequences encoding MRFGKR and KRK-STOP codons were therefore placed prior to, and following the peptide codon sequences, respectively. Finally, Gateway Cloning sites attB1 and attB2 sites were attached to the ends of the sequences. These final sequences (comprised of attB1::MRFGKR::peptide::KRK-STOP::attB2) were ordered from IDT (Integrated DNA Technologies) using their DNA Oligo and Ultramer DNA Oligo services, depending on the size of the oligo ordered. Both forward and reverse sequences were ordered (Supp. Table 1a).

Lyophilized oligos were prepared following IDT Annealing Oligonucleotides Protocol (https://www.idtdna.com/pages/education/decoded/article/annealing-oligonucleotides). In short, they were resuspended in Duplex Buffer (100 mM Potassium Acetate; 30 mM HEPES, pH 7.5; available from IDT), preheated to $94{ }^{\circ} \mathrm{C}$ to a final concentration of $40 \mu \mathrm{M}$. Complimentary oligo 
sequences were then mixed in equimolar ratios, and placed in a thermocycler at $94{ }^{\circ} \mathrm{C}$ for 2 minutes, prior to a stepwise cooling to room temperature.

Annealed oligos were used to perform a $\mathrm{BP}$ reaction with pDONR $\mathrm{p} 1-2$ donor vector to generate pENTRY clones (Gateway Cloning, ThermoFisher). Entry clones were then recombined with pDEST-527 (a gift from Dominic Esposito (Addgene plasmid \# 11518)) in LR reactions generating expression clones. The scramble control was generated in an identical manner, with the sequence between the cleavage sites being amplified from pL4440 (provided by Victor Ambros, University of Massachusetts Medical School, MA) (Supp. Table 1b). Purified plasmids were stored at $-20{ }^{\circ} \mathrm{C}$ or $-80{ }^{\circ} \mathrm{C}$ for long term storage.

\section{$\underline{\text { Peptide Plate Preparation }}$}

The expression clone for both the peptide of interest and the control was transformed into competent DH5 $\alpha$ cells $\left(\mathrm{NEB}{ }^{\circledR}\right.$ [New England Biolabs] 5-alpha Competent E. coli (High Efficiency) Cat\# C2987I).

Peptide-expressing cultures on LB agar plates $(10 \mathrm{~g} / \mathrm{L} \mathrm{NaCl}, 10 \mathrm{~g} / \mathrm{L}$ Tryptone, $5 \mathrm{~g} / \mathrm{L}$ Yeast Extract, $5 \mathrm{~g} / \mathrm{L}$ Agar) containing $100 \mu \mathrm{g} / \mu \mathrm{L}$ ampicillin (AMP), were stored at $4{ }^{\circ} \mathrm{C}$ for up to 2 months. From this plate, single colonies were selected for growth in $5 \mathrm{~mL}$ of LB media containing ampicillin at $37^{\circ} \mathrm{C}$ for 16 hours.

The optical density of the grown cultures $\left(\mathrm{OD}_{600}\right)$ was adjusted to $1.0 .75 \mu \mathrm{L}$ of $1.0 \mathrm{OD}_{600}$ peptide-expressing culture was plated onto $60 \mathrm{~mm}$ NGM agar plates $\left(50 \mathrm{mM} \mathrm{NaCl} .25 \mathrm{mM} \mathrm{KPO}_{4}\right.$ (pH 6.0), $1 \mathrm{mM} \mathrm{MgSO}_{4}, 1 \mathrm{mM} \mathrm{CaCl} 2,5 \mu \mathrm{g} / \mathrm{L}$ cholesterol, $17 \mathrm{~g} / \mathrm{L}$ agar, $2.5 \mathrm{~g} / \mathrm{L}$ peptone) containing $100 \mu \mathrm{g} / \mu \mathrm{L}$ AMP and $1 \mathrm{mM}$ isopropyl- $\beta$-D-thiogalactoside (IPTG) at room temperature for at least 8 hours prior to use, for no longer than 1 week.

Peptide Feeding 
All animals were maintained on bacterial lawns of OP50 E. coli, at $20^{\circ} \mathrm{C}$, on NGM agar plates until the start of experiments. Mutant or control animals were transferred onto lawns of DH5 $E$. coli expressing either scramble peptide or the rescue peptide-of-interest on NGM plates containing $100 \mu \mathrm{g} / \mu \mathrm{L}$ AMP and $1 \mathrm{mM}$ IPTG. Animals were reared on the peptide-expressing lawns for at least 48 hours at $20{ }^{\circ} \mathrm{C}$ before assaying for rescue of mutant phenotype at the appropriate developmental stage. See each section of the behavioral assay methods for the exact peptide feeding parameters.

\section{$\underline{\text { Size Comparison (trh-1) }}$}

The body morphology different of trh-1 mutants was compared to wild-type worms by body volume measurements. Wild-type (N2) and trh-1 animals were synchronized by embryonic starvation following alkaline hypochlorite protocols ${ }^{67}$. Ten gravid hermaphrodites from OP50 $E$. coli plates were picked into $30 \mu \mathrm{L}$ drops of alkaline hypochlorite solution (20\% sodium hypochlorite, $500 \mathrm{mM} \mathrm{KOH}$ ). Two drops were placed on either side of an unseeded NGM plate, resulting in 20 animals per plate. Plates were then incubated for 24 hours at $20^{\circ} \mathrm{C}$ before $\mathrm{L} 1$ larval animals washed with $1 \mathrm{~mL}$ M9 $\left(22 \mathrm{mM} \mathrm{KH}_{2} \mathrm{PO}_{4}, 42.25 \mathrm{mM} \mathrm{Na}_{2} \mathrm{HPO}_{4}, 85.5 \mathrm{mM} \mathrm{NaCl}, 1 \mathrm{mM}\right.$ $\mathrm{MgSO}_{4}$ ) per unseeded NGM plate. Allow L1 worms to settle into pellet before removing M9 supernatant. Repeat washing step 2 more times. Plate worm pellet onto NGM with $100 \mu \mathrm{g} / \mu \mathrm{L}$ AMP and $1 \mathrm{mM}$ IPTG plates containing $75 \mu \mathrm{L}$ peptide lawns.

After at 48 hours at $20^{\circ} \mathrm{C} 43$, animals were recorded using a Basler acA2500-14uM camera using WormLab software (WormLab 4.1; MBF Bioscience, 2017) for 65 seconds. Worm length, width, and area were calculated within the WormLab software (Supp. Figure 1 c-h). As the WormLab worm width metric is an average of cross-sections throughout the length of each worm, 
this was used to calculate the volume of a worm as a cylinder, with the Volume $=\pi *(0.5 * \text { width })^{2}$

\section{* length (Figure 2a, b, Supp. Figure 1a, b).}

\section{Chemotaxis Assay (ins-6)}

A salt chemotaxis assay was performed as previously described in ${ }^{68,69}$, to test the functionality of ins-6 after rescue-by-feeding. Wild-type (N2) and ins-6 worms were fed either scramble or INS-6 peptide passing 4-6 L4 larval onto an NGM plate containing $100 \mu \mathrm{g} / \mu \mathrm{L}$ AMP and $1 \mathrm{mM}$ IPTG with $75 \mu \mathrm{L}$ of peptide $\mathrm{OD}_{600}=1.0$. These worms were grown at $20^{\circ} \mathrm{C}$ for about 4 days until the progeny of the initial L4 worms were young adults.

The day prior to testing, a thin, $10 \mathrm{~mL}$ layer of agar was added to $10 \mathrm{~cm}$ petri dishes to generate a $10 \mathrm{~cm}$ Chemotaxis Plates (5 $\mathrm{mM} \mathrm{KPO}_{4}\left(\mathrm{pH}\right.$ 6.0), $1 \mu \mathrm{M} \mathrm{MgSO}_{4}, 1 \mu \mathrm{M} \mathrm{CaCl}_{2}, 20 \mathrm{~g} / \mathrm{L}$ agar, and 8 g/L Difco Nutrient Broth). To prepare the "high salt" plates, $750 \mathrm{mM} \mathrm{NaCl}$ was added prior to plate pouring. The high salt plate were stored at $4{ }^{\circ} \mathrm{C}$ for up to one month, while the Chemotaxis Plates were made one day prior to testing. To create the high and low salt plugs, the back end of a Pasteur pipette was used to punch a $5 \mathrm{~mm}$ plug out of each plate. These 2 plugs were placed on opposite edges of the plate. A $10 \mathrm{~mm}$ radius was be drawn around the location of the plugs (Figure 1 for schematic). Plates were stored, lightly covered, overnight at room temperature $\left(\sim 20{ }^{\circ} \mathrm{C},<40 \%\right.$ humidity).

The day of the assay, young adult worms, either control worms fed OP50 E. coli or peptidefed worms, were washed off peptide plates with M9. Worms were allowed to settle by gravity for 4 minutes before removing the supernatant, washing the worms. Worms were then washed with Chemotaxis Buffer $\left(5 \mathrm{mM} \mathrm{KPO}_{4}(\mathrm{pH} 6.0), 1 \mathrm{mM} \mathrm{MgSO}_{4}, 1 \mathrm{mM} \mathrm{CaCl}_{2}\right)$ three times.

To prepare the Chemotaxis plates for the assay, high and low salt plugs were removed with forceps, and the plates spotted with $1 \mu \mathrm{L}$ of $0.5 \mathrm{M}$ sodium azide $\left(\mathrm{NaN}_{3}\right)$. Approximately $30 \mu \mathrm{L}$ of 
worms in Chemotaxis Buffer were spotted onto the edge of the agar, between the location of the high and low salt gradient (Supp. Figure 2). Worms were left to chemotax for 1 hour before scoring the number of worms within the $10 \mathrm{~mm}$ radii of high and low salt areas.

\section{$\underline{\text { Excursion Assay }(p d f-1)}$}

The mate searching behavior of $p d f-1$ mutants was quantified in a food leaving assay. him-5 animals were used as wild-type control to ensure the presence of males. him-5 and pdf-1 animals were fed OP50, scramble peptide, PDF-1A, PDF-1B, or a 1:1 mixture of PDF-1A and PDF-1B cultures. Four to six larval L4 hermaphrodites were passed onto an NGM plate containing 100 $\mu \mathrm{g} / \mu \mathrm{L}$ AMP and $1 \mathrm{mM}$ IPTG with $75 \mu \mathrm{L}$ of peptide. These worms were grown at $20{ }^{\circ} \mathrm{C}$ for about 4 days until the male progeny of the initial L4 worms were young adults. The day prior to the assay, young adult male $p d f-1$ or him-5 worms were singled onto $60 \mathrm{~mm}$ plates containing lawns of either OP50 (NGM plates) or appropriate peptide cultures (NGM containing $100 \mu \mathrm{g} / \mu \mathrm{L}$ AMP and $1 \mathrm{mM}$ IPTG).

To determine the mate searching effects of $p d f-1$, we performed a food-leaving assay as described previously ${ }^{55,56,60}$, with modifications. In this assay, individuals were placed on a small food spot, and track patterns were scored at the indicated times. Assay plates were prepared one day prior to assaying on $100 \mathrm{~mm}$ plates with $10 \mathrm{~mL}$ of Leaving Assay media $(25 \mathrm{mM} \mathrm{KPO} 4(\mathrm{pH}$ 6.0), $1 \mathrm{mM} \mathrm{MgSO}_{4}, 1 \mathrm{mM} \mathrm{CaCl}_{2}, 50 \mathrm{mM} \mathrm{NaCl}, 2.5 \mathrm{~g} / \mathrm{L}$ Peptone, $17 \mathrm{~g} / \mathrm{L}$ Agar). On center of plate, $7 \mu \mathrm{L}$ of OP50 was added. Plates were lightly covered and stored at room temperature overnight $\left(\sim 20^{\circ} \mathrm{C},<40 \%\right.$ humidity).

On the day of the assay, a single male was plated on the assay plate and placed in a dark, $20^{\circ} \mathrm{C}$ incubator. At 2, 6, and 24 hours after the worms are plated, plates were scored for male worm tracks. Scored were separated into binned ranges ${ }^{60}$. "Never left food" indicates the absence of 
tracks outside the food spot. "Minor excursion" indicates that tracks were observed not beyond $10 \mathrm{~mm}$ from the food. "Major excursion" indicates the presence of tracks past the $1 \mathrm{~cm}$ boundary. We quantified the food leaving behavior at three different time points (2, 6, and 24 hours) ${ }^{55}$. (Figure 4a, Supp. Figure 3b) ${ }^{55}$.

We additionally quantified the mate searching defect of $p d f-1$ as a Probability of Leaving per hour $\left(\mathrm{P}_{\mathrm{L}}\right)$ (Figure 4b, Supp Figure. 3a, c) ${ }^{56}$. In this method, we reduce the analysis of the leaving behavior to a single value, by scoring the worms leaving the food lawn as Leavers (traveling beyond $35 \mathrm{~mm}$ from the food source) or Non-Leavers (did not travel further than $35 \mathrm{~mm}$ from center of food).

\section{Statistics and Reproducibility}

\section{$\underline{\text { Size Comparisons }}$}

Two to four plates were recorded per day for at least three days to generate data sets. Control plates of N2 and trh-1 animals raised on the scramble peptide were grown alongside every rescue feeding. Each "worm track" was considered an $n=1$. Tracks were excluded if (1) worm tracks less than 10 seconds, or (2) worms were further than two standard deviations from the mean metric. Following tests for normality, comparisons were made using either Mann-Whitney tests for direct comparisons between N2 and trh-1 animals reared on OP50, or Kruskal-Wallis non-parametric ANOVAs and Dunn's multiple comparisons tests for animals raised on peptide feeding strains. Comparisons were made for metrics: length (Supp. Figure 1c, d), width (Supp. Figure 1e, f), area (Supp. Figure 1g, h), and volume (Figure 2a, b, and Supp. Figure 1a, b).

\section{$\underline{\text { Chemotaxis Assay }}$}

Young adult hermaphrodites are tested in the Chemotaxis Assay with no more than three replicates per day, over a minimum of three days, with 100-200 worms/assay plate. The 
Chemotaxis Index (CI) was calculated as $C I=\frac{\# \text { worms in high salt-\# ofworms in low salt }}{\text { total \# } \text { worms }}$. At least 10 plates were assayed in each condition: OP50 control, scramble fed, and INS-6 fed. Plates were excluded from final calculations if (1) the total number of worms on the assay plate was $<20$, or (2) if the plate CI was greater than two standard deviations from the average CI. Conditions were compared using Two-tailed $t$-tests with samples of equal variable to compare between two conditions with small samples or ANOVA followed by Bonferroni's multiple comparison for multiple condition comparisons.

\section{Excursion Assay}

The assay was performed across at least two days per condition, with at least $n=50$, wherein each assay plate with one male is equal to $n=1$. In all experiments, the investigators were blinded to genotype. Worm in the $>35 \mathrm{~mm}$ from the center of food bin were scored as "leavers" 56. The probability of leaving per hour (Probability of Leaving $\left(\mathrm{P}_{\mathrm{L}}\right)$ ) was calculated using an $\mathrm{R}$ script developed in ${ }^{55}$, first cited in ${ }^{56}$, with assistance by (Personal Communications to Barrios, 2020). $P_{L}$ was calculated by the "hazard obtained by fitting an exponential parametric survival model to the censored data using maximum likelihood" (Supp. Figure 3a) ${ }^{56}$. The $\mathrm{P}_{\mathrm{L}} \mathrm{h}^{-1}$ values for all $p d f-1$ animals fed scramble or peptide rescue were compared to him-5 worms fed scramble using an ANOVA followed by Bonferroni's multiple comparison (Figure 4b, Supp. Figure 3c).

\section{Data Availability}

The raw data for all figures is available with this manuscript. Additionally, a summary containing the average, $\mathrm{n}$, standard error measure, and associated statistical test is also available.

\section{Acknowledgements}


We would like to thank Jeffrey Marsh for assistance in running the Chemotaxis Assays. We would like to thank Dr. Arantza Barrios for help in executing the leaving assay analysis in R. We extend our thanks to Dr. Shreekanth Chalasani and Dr. Douglas Portman for their insights and updates to method for testing the phenotypes related to ins- 6 and $p d f-1$, respectively. Thank you to Dr. Isabel Beets for her insights into the trh-1 analysis. This work was funded by NIH R01DC016058 (JS).

\section{Author's Contribution}

EMD, DKR and JS designed all experiments, EMD and DKR performed all experiments and statistical analysis. EMD co-wrote the paper with DKR and JS.

\section{Ethics Declaration}

The authors declare no competing financial or non-financial interests as defined by Nature Research. 


\section{$\underline{\text { References }}$}

1 Ghosh, D. D., Nitabach, M. N., Zhang, Y. \& Harris, G. Multisensory integration in C. elegans. Curr Opin Neurobiol 43, 110-118, doi:10.1016/j.conb.2017.01.005 (2017).

2 Mesulam, M. M. From sensation to cognition. Brain 121 ( Pt 6), 1013-1052, doi:10.1093/brain/121.6.1013 (1998).

3 Gonzalez-Suarez, A. D. \& Nitabach, M. N. Peptide-Mediated Neurotransmission Takes Center Stage. Trends Neurosci 41, 325-327, doi:10.1016/j.tins.2018.03.013 (2018).

4 Srinivasan, J. et al. A blend of small molecules regulates both mating and development in Caenorhabditis elegans. Nature 454, 1115-1118, doi:10.1038/nature07168 (2008).

5 Jang, H. et al. Neuromodulatory state and sex specify alternative behaviors through antagonistic synaptic pathways in C. elegans. Neuron 75, 585-592, doi:10.1016/j.neuron.2012.06.034 (2012).

6 Macosko, E. Z. et al. A hub-and-spoke circuit drives pheromone attraction and social behaviour in C. elegans. Nature 458, 1171-1175, doi:10.1038/nature07886 (2009).

7 Chacko, R. et al. Data based predictive models for odor perception. Scientific Reports 10, 17136, doi:10.1038/s41598-020-73978-1 (2020).

8 Malnic, B., Hirono, J., Sato, T. \& Buck, L. B. Combinatorial receptor codes for odors. Cell 96, 713723, doi:10.1016/s0092-8674(00)80581-4 (1999).

$9 \quad$ Li, C. \& Kim, K. Neuropeptides. WormBook, 1-36, doi:10.1895/wormbook.1.142.1 (2008).

10 Dale Purves, G. J. A., David Fitzpatrick, William C Hall, Anthony-Samuel LaMantia, Richard D Mooney, Michael L Platt, Leonard E White.

Neuroscience. 6 edn, (Oxford University Press, 2018).

11 Frooninckx, L. et al. Neuropeptide GPCRs in C. elegans. Frontiers in Endocrinology 3, doi:10.3389/fendo.2012.00167 (2012).

12 Nusbaum, M. P., Blitz, D. M. \& Marder, E. Functional consequences of neuropeptide and smallmolecule co-transmission. Nat Rev Neurosci 18, 389-403, doi:10.1038/nrn.2017.56 (2017).

13 Beets, I. et al. Vasopressin/oxytocin-related signaling regulates gustatory associative learning in $C$. elegans. Science 338, 543-545, doi:10.1126/science.1226860 (2012).

14 Gruber, C. W. Physiology of invertebrate oxytocin and vasopressin neuropeptides. Experimental Physiology 99, 55-61, doi:https://doi.org/10.1113/expphysiol.2013.072561 (2014).

15 Insel, T. R. \& Young, L. J. The neurobiology of attachment. Nature Reviews Neuroscience 2, 129136, doi:10.1038/35053579 (2001).

16 Willets, J. M. et al. Regulation of oxytocin receptor responsiveness by G protein-coupled receptor kinase 6 in human myometrial smooth muscle. Mol Endocrinol 23, 1272-1280, doi:10.1210/me.2009-0047 (2009).

17 Lukas, M. et al. The Neuropeptide Oxytocin Facilitates Pro-Social Behavior and Prevents Social Avoidance in Rats and Mice. Neuropsychopharmacology 36, 2159-2168, doi:10.1038/npp.2011.95 (2011).

18 Odekunle, E. A. et al. Ancient role of vasopressin/oxytocin-type neuropeptides as regulators of feeding revealed in an echinoderm. BMC Biology 17, 60, doi:10.1186/s12915-019-0680-2 (2019).

19 Garrison, J. L. et al. Oxytocin/vasopressin-related peptides have an ancient role in reproductive behavior. Science 338, 540-543, doi:10.1126/science.1226201 (2012).

20 White, J. G., Southgate, E., Thomson, J. N. \& Brenner, S. The structure of the nervous system of the nematode Caenorhabditis elegans. Philos Trans R Soc Lond B Biol Sci 314, 1-340 (1986).

21 Sammut, M. et al. Glia-derived neurons are required for sex-specific learning in C. elegans. Nature 526, 385-390, doi:10.1038/nature15700 (2015).

22 Li, C., Kim, K. \& Nelson, L. S. FMRFamide-related neuropeptide gene family in Caenorhabditis elegans. Brain Res 848, 26-34, doi:10.1016/s0006-8993(99)01972-1 (1999).

23 Pierce, S. B. et al. Regulation of DAF-2 receptor signaling by human insulin and ins-1, a member of the unusually large and diverse C. elegans insulin gene family. Genes Dev 15, 672-686, doi:10.1101/gad.867301 (2001). 
24 Nathoo, A. N., Moeller, R. A., Westlund, B. A. \& Hart, A. C. Identification of neuropeptide-like protein gene families in Caenorhabditiselegans and other species. Proc Natl Acad Sci U S A 98, 14000-14005, doi:10.1073/pnas.241231298 (2001).

25 Van Bael, S. et al. Mass spectrometric evidence for neuropeptide-amidating enzymes in Caenorhabditis elegans. J Biol Chem 293, 6052-6063, doi:10.1074/jbc.RA117.000731 (2018).

26 Hobert, O. in WormBook: The Online Review of C. elegans Biology (Pasadena, CA, 2005-2018).

27 Barrios, A., Ghosh, R., Fang, C., Emmons, S. W. \& Barr, M. M. PDF-1 neuropeptide signaling modulates a neural circuit for mate-searching behavior in C. elegans. Nature Neuroscience 15, 1675-1684, doi:10.1038/nn.3253 (2012).

28 Hussey, R. et al. Oxygen-sensing neurons reciprocally regulate peripheral lipid metabolism via neuropeptide signaling in Caenorhabditis elegans. PLoS genetics 14, e1007305-e1007305, doi:10.1371/journal.pgen.1007305 (2018).

29 Nath, R. D., Chow, E. S., Wang, H., Schwarz, E. M. \& Sternberg, P. W. C. elegans Stress-Induced Sleep Emerges from the Collective Action of Multiple Neuropeptides. Current biology 26, 24462455, doi:10.1016/j.cub.2016.07.048 (2016).

30 Nelson, M. D. et al. FRPR-4 Is a G-Protein Coupled Neuropeptide Receptor That Regulates Behavioral Quiescence and Posture in Caenorhabditis elegans. PLoS One 10, e0142938, doi:10.1371/journal.pone.0142938 (2015).

31 Van Bael, S., Edwards, S. L., Husson, S. J. \& Temmerman, L. Identification of Endogenous Neuropeptides in the Nematode C. elegans Using Mass Spectrometry. Methods Mol Biol 1719, 271-291, doi:10.1007/978-1-4939-7537-2_18 (2018).

32 TC, E. Transformation and microinjection. . WormBook: The Online Review of C. elegans Biology (2006).

33 Rieckher, M. \& Tavernarakis, N. Caenorhabditis elegans Microinjection. Bio Protoc 7, e2565, doi:10.21769/BioProtoc.2565 (2017).

34 Conte, D., Jr., MacNeil, L. T., Walhout, A. J. M. \& Mello, C. C. RNA Interference in Caenorhabditis elegans. Curr Protoc Mol Biol 109, 26.23.21-26.23.30, doi:10.1002/0471142727.mb2603s109 (2015).

35 Timmons, L., Court, D. L. \& Fire, A. Ingestion of bacterially expressed dsRNAs can produce specific and potent genetic interference in Caenorhabditis elegans. Gene 263, 103-112, doi:10.1016/s0378-1119(00)00579-5 (2001).

36 Timmons, L. \& Fire, A. Specific interference by ingested dsRNA. Nature 395, 854, doi:10.1038/27579 (1998).

37 Fire, A. et al. Potent and specific genetic interference by double-stranded RNA in Caenorhabditis elegans. Nature 391, 806-811, doi:10.1038/35888 (1998).

$38 \mathrm{Xu}$, J. et al. Feeding recombinant E. coli with GST-mBmKTX fusion protein increases the fecundity and lifespan of Caenorhabditis elegans. Peptides 89, 1-8, doi:10.1016/j.peptides.2017.01.003 (2017).

39 Fraser, A. G. et al. Functional genomic analysis of $C$. elegans chromosome I by systematic RNA interference. Nature 408, 325-330, doi:10.1038/35042517 (2000).

40 Kamath, R. S., Martinez-Campos, M., Zipperlen, P., Fraser, A. G. \& Ahringer, J. Effectiveness of specific RNA-mediated interference through ingested double-stranded RNA in Caenorhabditis elegans. Genome Biol 2 (2001).

41 Reece-Hoyes, J. S. \& Walhout, A. J. M. Gateway Recombinational Cloning. Cold Spring Harb Protoc 2018, doi:10.1101/pdb.top094912 (2018).

42 Petersen, L. K. \& Stowers, R. S. A Gateway MultiSite recombination cloning toolkit. PLoS One 6, e24531, doi:10.1371/journal.pone.0024531 (2011).

43 Van Sinay, E. et al. Evolutionarily conserved TRH neuropeptide pathway regulates growth in Caenorhabditis elegans. Proc Natl Acad Sci $U$ S A 114, E4065-e4074, doi:10.1073/pnas.1617392114 (2017). 
44 Husson, S. J., Clynen, E., Baggerman, G., Janssen, T. \& Schoofs, L. Defective processing of neuropeptide precursors in Caenorhabditis elegans lacking proprotein convertase 2 (KPC-2/EGL3): mutant analysis by mass spectrometry. J Neurochem 98, 1999-2012, doi:10.1111/j.14714159.2006.04014.x (2006).

45 Salem, J. B., Nkambeu, B., Arvanitis, D. N. \& Beaudry, F. Deciphering the Role of EGL-3 for Neuropeptides Processing in Caenorhabditis elegans Using High-Resolution Quadrupole-Orbitrap Mass Spectrometry. Neurochem Res 43, 2121-2131, doi:10.1007/s11064-018-2636-2 (2018).

46 Mullur, R., Liu, Y. Y. \& Brent, G. A. Thyroid hormone regulation of metabolism. Physiol Rev 94, 355-382, doi:10.1152/physrev.00030.2013 (2014).

47 Galas, L. et al. TRH acts as a multifunctional hypophysiotropic factor in vertebrates. Gen Comp Endocrinol 164, 40-50, doi:10.1016/j.ygcen.2009.05.003 (2009).

48 Zečić, A., Dhondt, I. \& Braeckman, B. P. The nutritional requirements of Caenorhabditis elegans. Genes \& Nutrition 14, 15, doi:10.1186/s12263-019-0637-7 (2019).

49 Shtonda, B. B. \& Avery, L. Dietary choice behavior in Caenorhabditis elegans. J Exp Biol 209, 89-102, doi:10.1242/jeb.01955 (2006).

50 Chen, Z. et al. Two insulin-like peptides antagonistically regulate aversive olfactory learning in $C$. elegans. Neuron 77, 572-585, doi:10.1016/j.neuron.2012.11.025 (2013).

51 Hung, W. L., Wang, Y., Chitturi, J. \& Zhen, M. A Caenorhabditis elegans developmental decision requires insulin signaling-mediated neuron-intestine communication. Development 141, 17671779, doi:10.1242/dev.103846 (2014).

52 Hua, Q.-X. et al. A divergent INS protein in Caenorhabditis elegans structurally resembles human insulin and activates the human insulin receptor. Genes Dev 17, 826-831, doi:10.1101/gad.1058003 (2003).

53 Zheng, S. et al. A functional study of all 40 Caenorhabditis elegans insulin-like peptides. J Biol Chem 293, 16912-16922, doi:10.1074/jbc.RA118.004542 (2018).

54 Leinwand, S. G. \& Chalasani, S. H. Neuropeptide signaling remodels chemosensory circuit composition in Caenorhabditis elegans. Nat Neurosci 16, 1461-1467, doi:10.1038/nn.3511 (2013).

55 Barrios, A., Ghosh, R., Fang, C., Emmons, S. W. \& Barr, M. M. PDF-1 neuropeptide signaling modulates a neural circuit for mate-searching behavior in C. elegans. Nat Neurosci 15, 1675-1682, doi:10.1038/nn.3253 (2012).

56 Lipton, J., Kleemann, G., Ghosh, R., Lints, R. \& Emmons, S. W. Mate searching in Caenorhabditis elegans: a genetic model for sex drive in a simple invertebrate. The Journal of neuroscience : the official journal of the Society for Neuroscience 24, 7427-7434, doi:10.1523/JNEUROSCI.174604.2004 (2004).

57 Reilly, D. K. Neuromodulation of Sex-Specific Pheromone-Mediated Behaviors PhD thesis, Worcester Polytechnic Institute, (2020).

58 Janssen, T. et al. Functional characterization of three $\mathrm{G}$ protein-coupled receptors for pigment dispersing factors in Caenorhabditis elegans. $J$ Biol Chem 283, 15241-15249, doi:10.1074/jbc.M709060200 (2008).

59 Janssen, T. et al. Discovery and characterization of a conserved pigment dispersing factor-like neuropeptide pathway in Caenorhabditis elegans. J Neurochem 111, 228-241, doi:10.1111/j.14714159.2009.06323.x (2009).

60 Ryan, D. A. et al. Sex, age, and hunger regulate behavioral prioritization through dynamic modulation of chemoreceptor expression. Curr Biol 24, 2509-2517, doi:10.1016/j.cub.2014.09.032 (2014).

61 Reilly, D. K. et al. Distinct Neuropeptide-Receptor Modules Regulate a Sex-Specific Behavioral Response to a Pheromone. bioRxiv, 2020.2012.2009.417857, doi:10.1101/2020.12.09.417857 (2020).

62 Yang, N. J. \& Hinner, M. J. Getting across the cell membrane: an overview for small molecules, peptides, and proteins. Methods Mol Biol 1266, 29-53, doi:10.1007/978-1-4939-2272-7_3 (2015). 
63 Meissner, B., Boll, M., Daniel, H. \& Baumeister, R. Deletion of the intestinal peptide transporter affects insulin and TOR signaling in Caenorhabditis elegans. J Biol Chem 279, 36739-36745, doi:10.1074/jbc.M403415200 (2004).

64 Rao, M. \& Sockanathan, S. Molecular mechanisms of RNAi: Implications for development and disease. Birth Defects Research Part C: Embryo Today: Reviews 75, 28-42, doi:https://doi.org/10.1002/bdrc.20030 (2005).

65 Bernstein, E., Caudy, A. A., Hammond, S. M. \& Hannon, G. J. Role for a bidentate ribonuclease in the initiation step of RNA interference. Nature 409, 363-366, doi:10.1038/35053110 (2001).

66 Seydoux, G. \& Fire, A. Soma-germline asymmetry in the distributions of embryonic RNAs in Caenorhabditis elegans. Development 120, 2823-2834 (1994).

67 Stiernagle, T. Maintenance of C. elegans. WormBook, 1-11, doi:10.1895/wormbook.1.101.1 (2006).

68 Leinwand, S. G. \& Chalasani, S. H. Neuropeptide signaling remodels chemosensory circuit composition in Caenorhabditis elegans. Nature neuroscience 16, 1461-1467, doi:10.1038/nn.3511 (2013).

69 Bargmann, C. I. \& Horvitz, H. R. Chemosensory neurons with overlapping functions direct chemotaxis to multiple chemicals in C. elegans. Neuron 7, 729-742 (1991). 


\section{$\underline{\text { Figure Captions }}$}

\section{Figure 1. Overview of the Rescue-By-Feeding Technique to Rescue Neuropeptide Function.}

a) Design of an expression vector containing the peptide sequence of interest. The vector sequence includes Gateway Cloning sites attR1 and attR2, a 6x-histidine tag (6x-His), and MRFGKR and KRK-STOP sequences flanking the peptide sequence of interest. This vector is transformed into E. coli DH5 $\alpha$ cells allowing for the expression of peptides. The bacteria expressing the neuropeptides is then fed to neuropeptide loss-of-function worms and assayed for rescue of behavior. b) Different assays used to quantify behavioral activity. We used three different assays for the quantification of rescue; (1) Size Comparison, (2) Chemotaxis and (3) Excursion Assay. For Size Comparison, mutant worms are fed the peptide for 48 hours before assaying for body morphology on an automated worm tracker. In the second assay, Chemotaxis, we used an $\mathrm{NaCl}$ gradient chemotaxis assay to salt attraction of worms of rescued neuropeptides. The Excursion Assay quantified the ability for males to leave a food source in search of mates. Minor Excursion denotes worms that did not leave the food source. Major Excursion denotes worms that left the

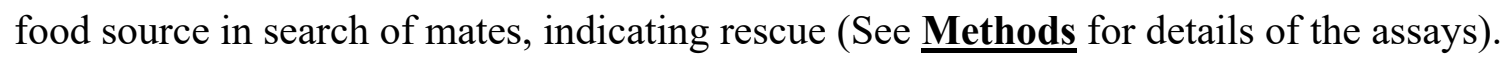

Figure 2. Feeding of TRH-1 Peptides Rescues the Body Volume Defects in trh-1 Mutants. a) trh-1 mutant worms exhibit body volume defects. trh-1 mutants show a reduced body volume compared with wild-type worms when fed E. coli OP50 (Mann-Whitney test, ${ }^{* *} p=0.0012$ ). b) Feeding of TRH-1 peptides results in restoration of body volume in trh-1 lof worms. trh-1 mutant worms fed with scramble peptide, display significant increase in body volume feeding compared to wild-type animals. trh-1 mutants fed either TRH-1A or TRH-1B or even a combination of both exhibit a restoration of wild-type body volume. Error bars denote SEM. $n$ values denoted in graph. Kruskal-Wallis followed by Dunn's multiple comparisons, **/\#\# $p<0.01$, \#\#\#\# $p<0.0001$, 
*denote mutant worms compared to wild-type control, \#denote mutant worm condition compared to mutant worms fed scramble peptide.

Figure 3. Chemotaxis Defects of ins-6 Neuropeptide Mutants are Rescued by Feeding the INS-6 Peptide. a) Chemotaxis Index to $750 \mathrm{mM} \mathrm{NaCl}$ of wild-type (WT), ins-6 loss of function, and genetic ins-6 rescue (ins-6;Pins-6;ins-6), animals fed E. coli OP50. Animals with loss-offunction ins-6 gene exhibit significant decreased attraction and genetic rescue of ins- 6 results in a partial rescue of chemotaxis. b) Chemotaxis Index of peptide fed worms to $750 \mathrm{mM} \mathrm{NaCl}$. ins-6 lof worms fed scramble display significantly lower chemotaxis compared to scramble-fed wild type animals. Feeding of INS-6 peptide to ins-6 lof worms results in complete rescue of $\mathrm{NaCl}$ chemotaxis. Overexpression of INS-6 does not result in changes in attraction towards $750 \mathrm{mM}$ $\mathrm{NaCl} . n$ values are denoted in graphs. Error bars denote SEM. One-Way ANOVA, followed by Bonferroni's Correction $* p<0.05, * * p<0.01, * * * p<0.001, * * * * p<0.0001$, comparisons noted with line over bars.

Figure 4. pdf-1 lof males fed discrete PDF-1 peptides differentially rescue food-leaving behavior. a) Percent of male worms leaving food across time is used to visualize the location of the males a different time points. him-5 males serve as the wild-type worms in this assay compared to males deficient in $p d f-1$ fed PDF-1 peptide to rescue behavior. At each time point the percent of worm within each boundary is noted (Major Excursion is beyond $10 \mathrm{~mm}$ radius of the food (purple), Minor Excursion is worms who left food but stayed within $10 \mathrm{~mm}$ (pink), and those remaining on food were classified as Never Left Food (yellow)). b) Probability of Leaving. To compare the leaving behavior of the worms as a likelihood of the worms seeking to travel beyond $35 \mathrm{~mm}$ from the food. $n$; him-5 males fed scramble $=55, p d f-1$ males fed scramble $=53, p d f-1$ males fed PDF-1A $=58, p d f-1$ males fed PDF-1B $=51, p d f-1$ males fed PDF-1A and PDF-1B = 
bioRxiv preprint doi: https://doi.org/10.1101/2021.05.10.443513; this version posted May 11, 2021. The copyright holder for this preprint (which was not certified by peer review) is the author/funder. All rights reserved. No reuse allowed without permission.

51). Error bars denote SEM. ANOVA, followed by Bonferroni's Correction, ***/\#\#\# $p<0.001$, \#\#\#\# $p<0.0001, *$ denote mutant worms compared to wild-type control, \#denote mutant worm condition compared to mutant worms fed scramble peptide. 
a)

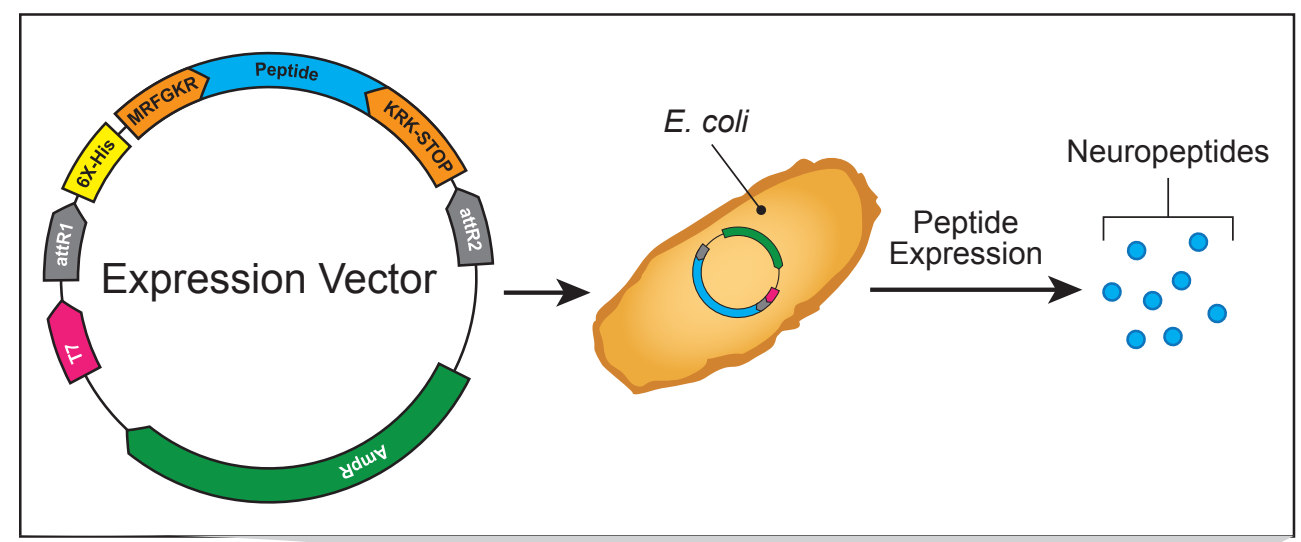

b)

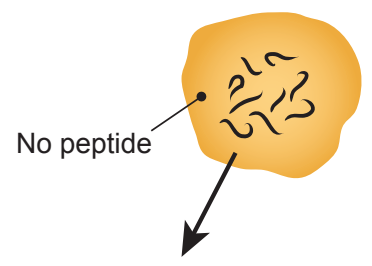

\section{Peptide Feeding}

Null mutant phenotypes
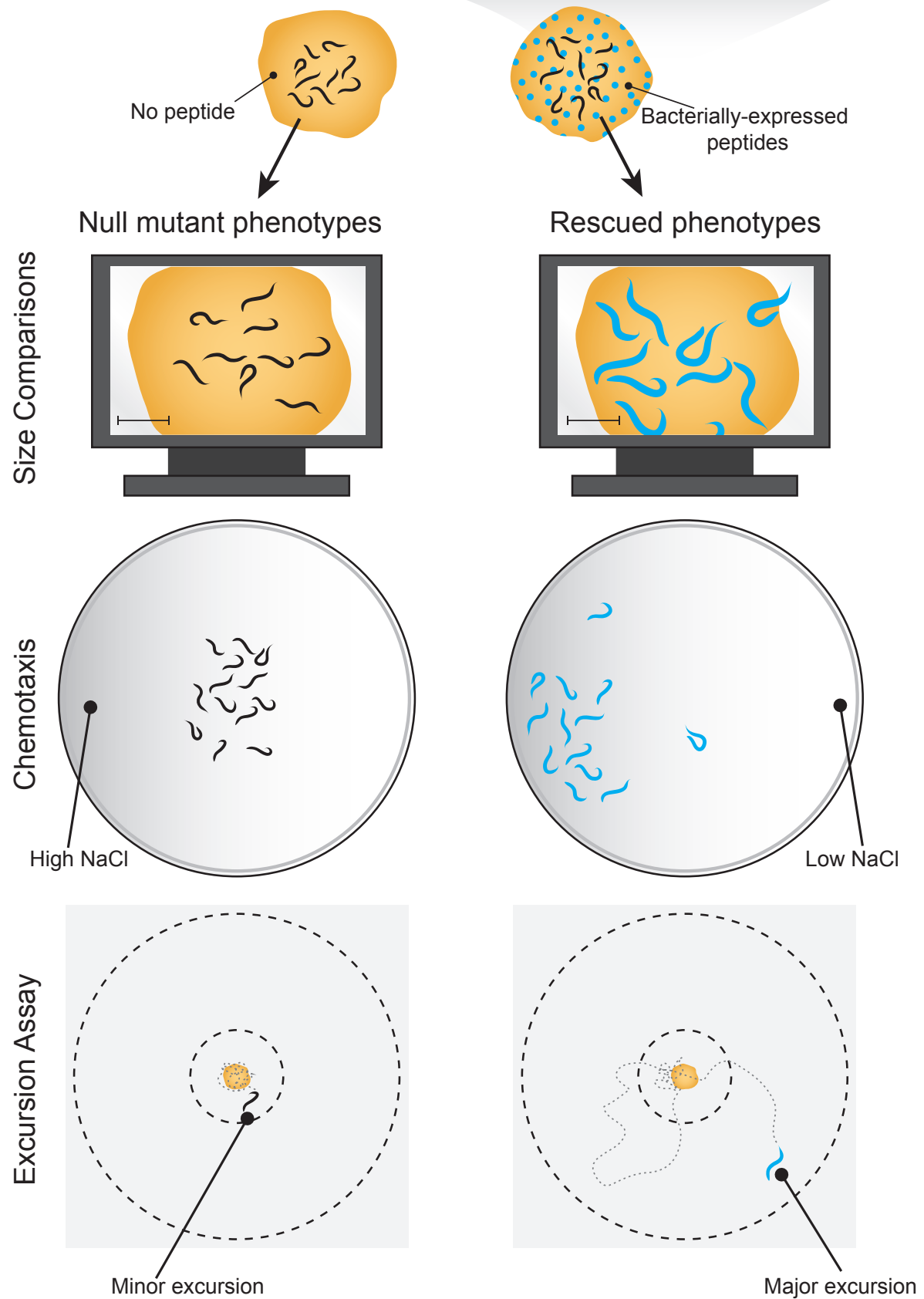

Figure-1 
bioRxiv preprint doi: https://doi.org/10.1101/2021.05.10.443513; this version posted May 11, 2021. The copyright holder for this preprint (which was not certified by peer review) is the author/funder. All rights reserved. No reuse allowed without permission.

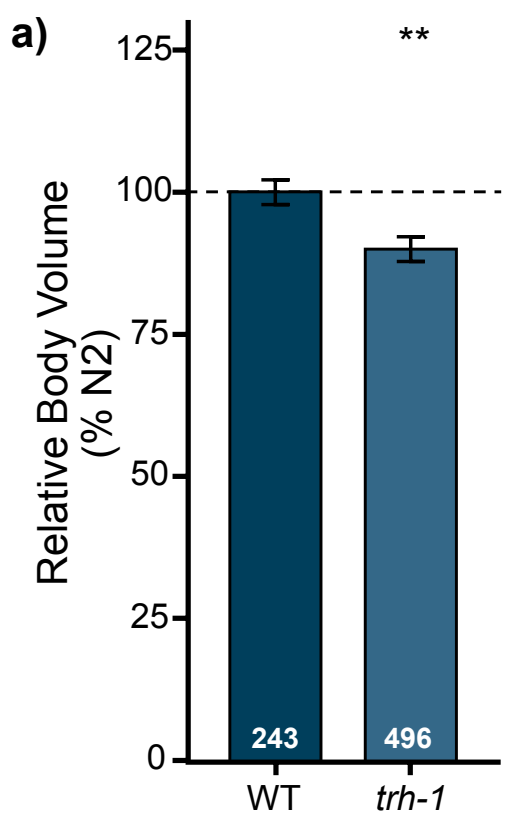

b)

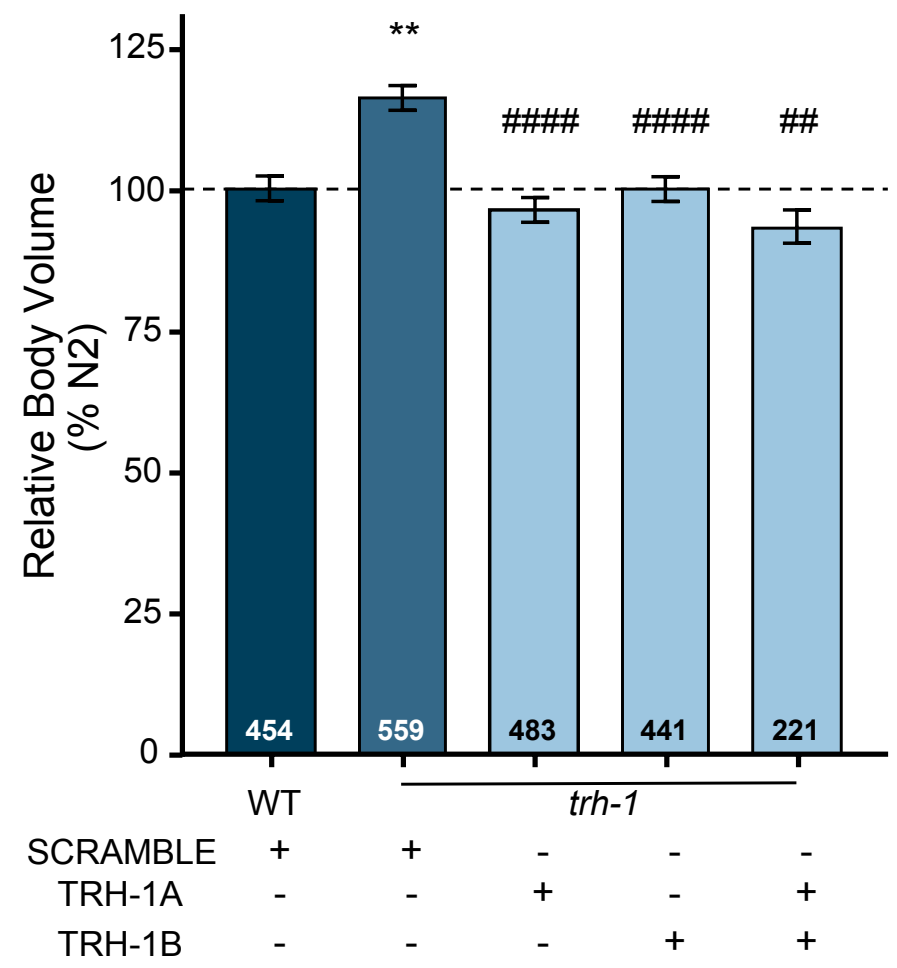

Figure-2 
a)

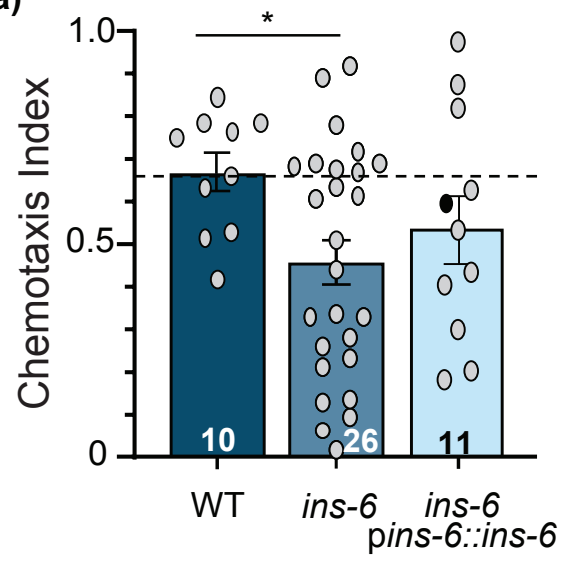

b)

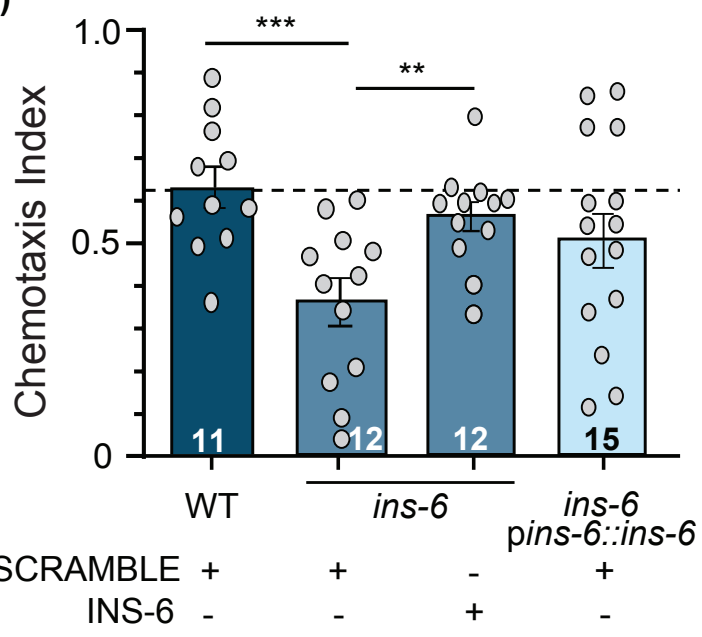


bioRxiv preprint doi: https://doi.org/10.1101/2021.05.10.443513; this version posted May 11, 2021. The copyright holder for this preprint (which was not certified by peer review) is the author/funder. All rights reserved. No reuse allowed without permission.

a)

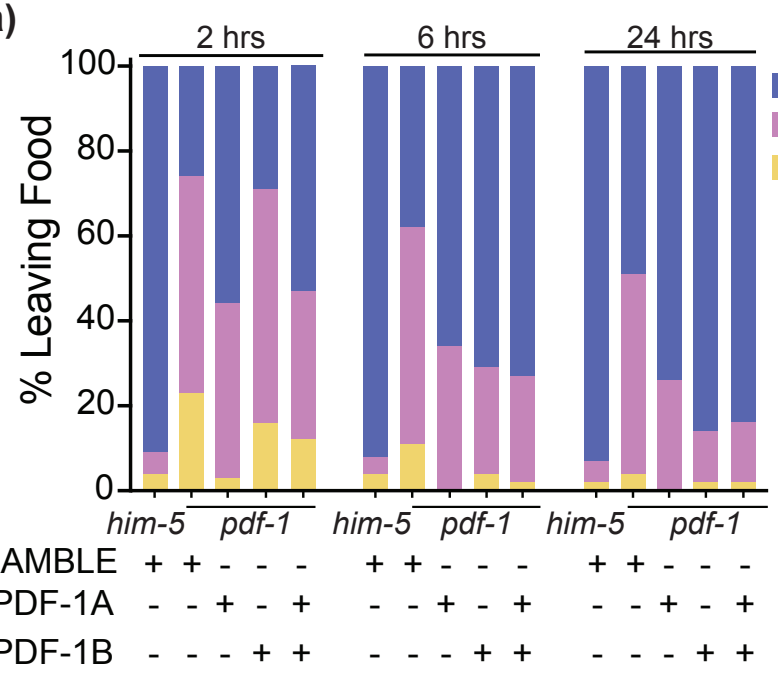

b)

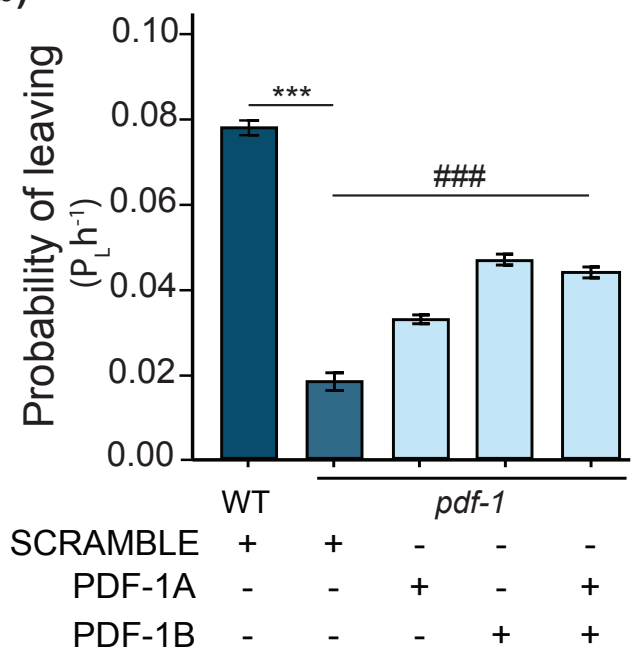




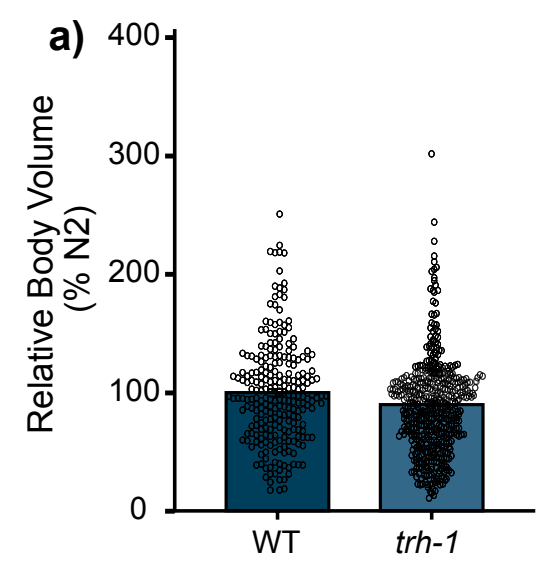

e)

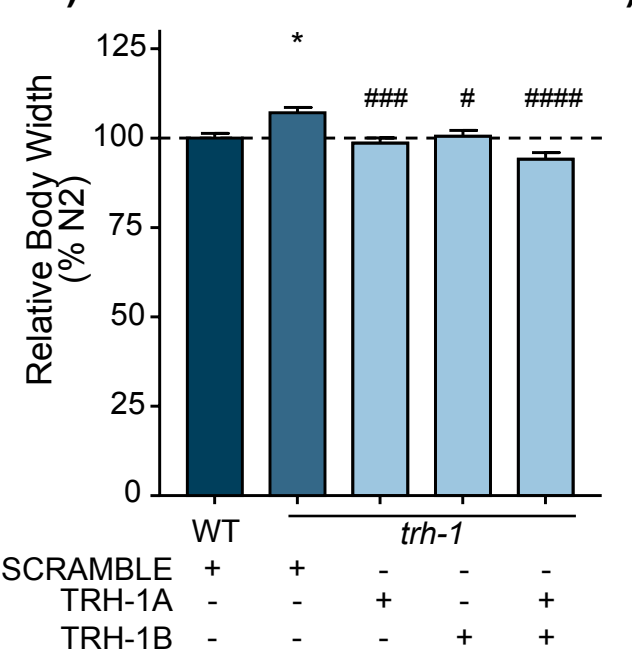

b) 60

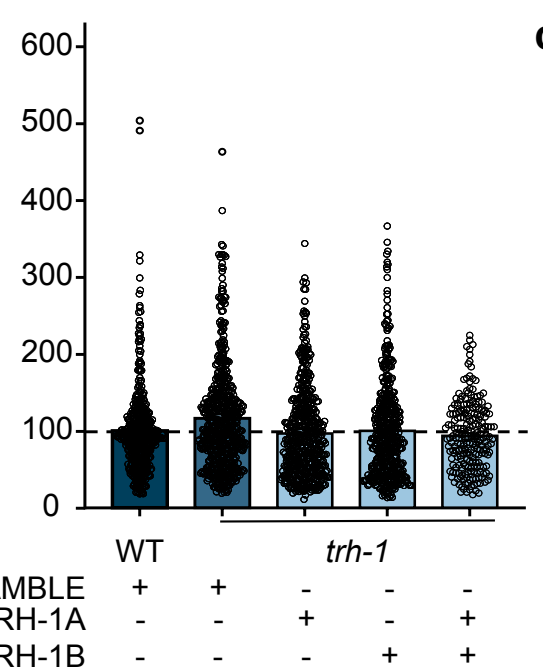

f)

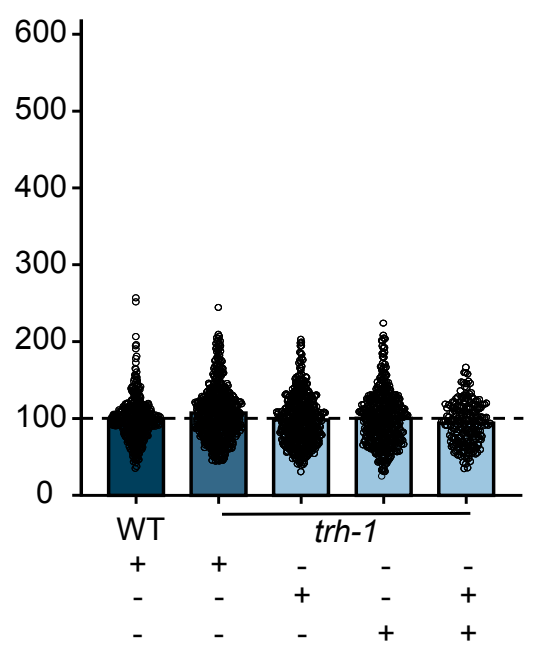

c)

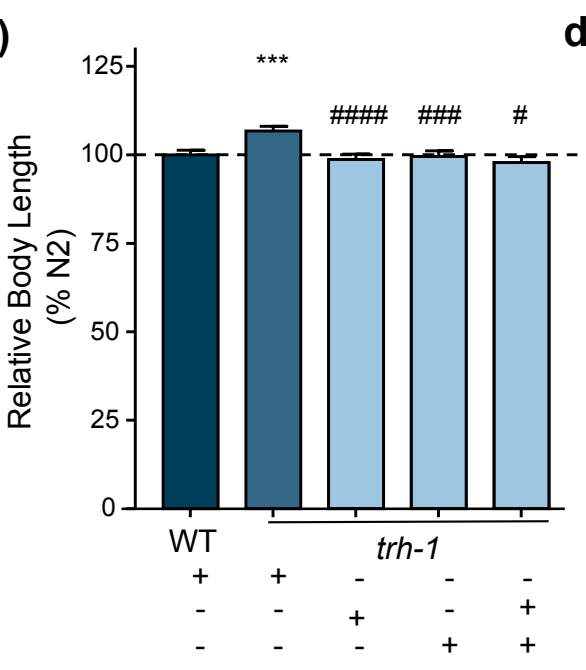

g)

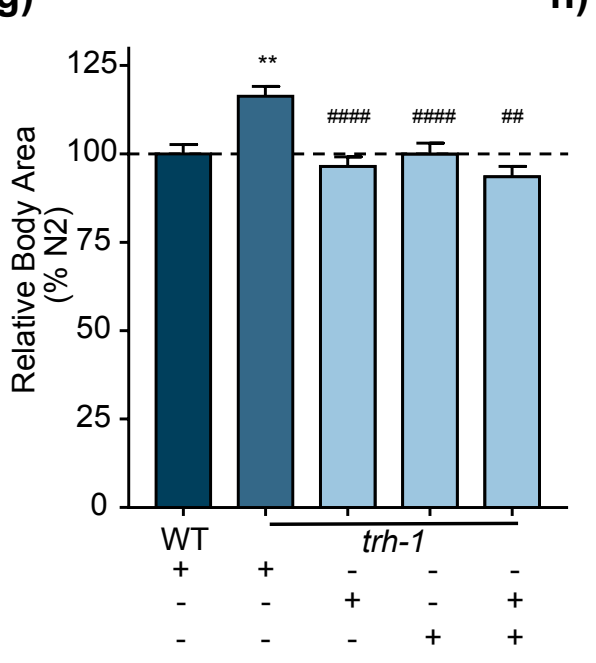

d) 60

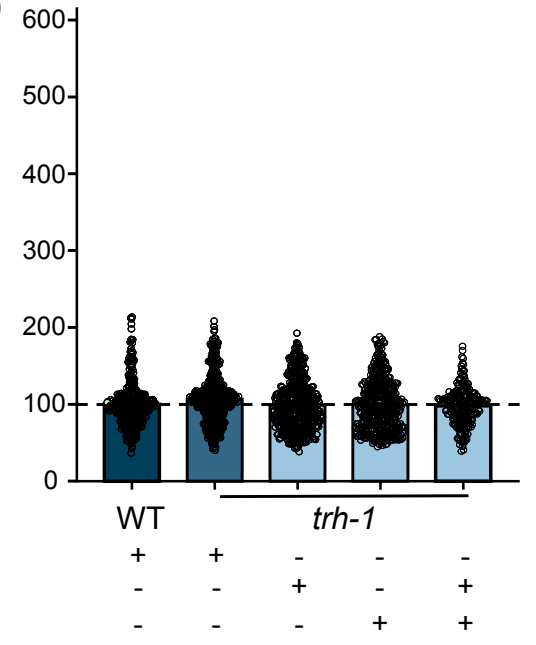

h)

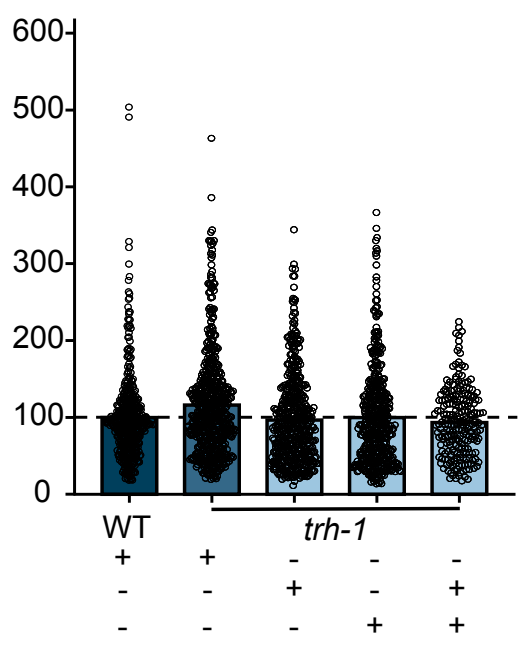




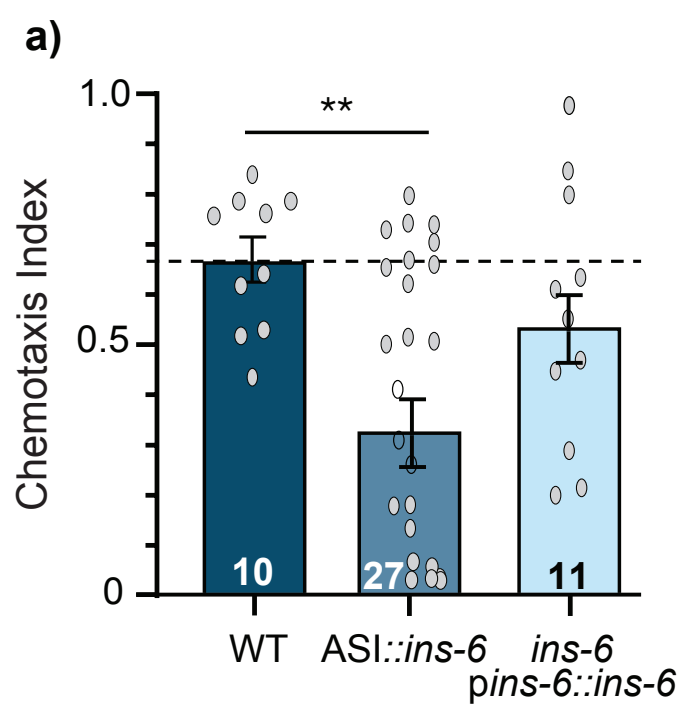

b)

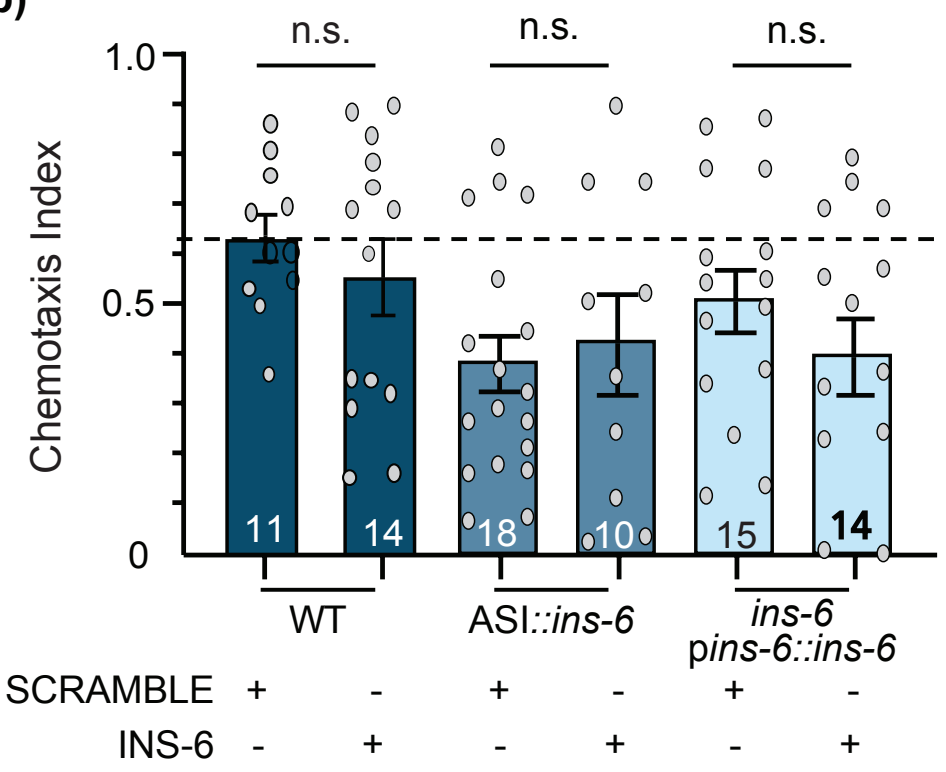

